\title{
O caminho para Deus: uma aproximação do pensamento de Balthasar sobre a busca por Deus
}

\author{
The pat to God: \\ an approach to Balthasar on the search for God
}

Geraldo Luiz Borges Hackmann Rafael Martins Fernandes

\section{Resumo}

$\mathrm{O}$ artigo visa apresentar como um dos grandes teólogos do século XX, o suíço Hans Urs von Balthasar, apresenta seu pensamento sobre a busca de Deus por parte do ser humano em sua obra Spiritus Creator. Para chegar à possibilidade da existência de Deus, o autor parte de dois pressupostos: a analogia entis e o amor maternal, a partir do qual a relação pessoal entre a mãe e o filho desperta no filho o amor e a descoberta de si mesmo como pessoa, do outro e do mundo. Assim, a pessoa humana está apta para descobrir a Deus como amor pessoal. Tal descoberta passa pela dialética do tu humano ao Tu divino, quando a natureza humana é auxiliada pela graça divina. Por fim, se faz um diálogo entre as conhecidas cinco vias de Tomás de Aquino e Balthasar.

Palavras-chave: Balthasar. Busca de Deus. Mundo de hoje. Amor.

\begin{abstract}
This article aims at presenting as one of the great theologians of the XX century, the Swiss Hans Urs von Balthasar. It presents his thought about the search for God on the part of the human being in his work Spiritus Creator. In
\end{abstract}


order to reach the possibility of the existence of God, the author draws from two presuppositions: the antologia antis and maternal love, from which the personal relationship between mother and son awakens love in the son and the discovery of himself as a person, the other and the world. Thus, the human person is able to discover God as personal love. This discovery goes through the dialectic of the human you to the divine You, when human nature is assisted by divine grace. Finally, a dialogue is made between the five well-known ways of Thomas Aquinas and Balthasar in the process of discovery of God.

Keywords: Balthasar. Search for God. Today's world. Love.

\section{Introdução}

Hoje, do ponto de vista religioso, é comum a afirmação de que a humanidade se encontra em uma situação de pós-cristianismo, pela ausência do referencial religioso na cultura atual. ${ }^{1}$ Depara-se simultaneamente com uma contundente negação de Deus ao lado de sua afirmação convicta. Todavia, o tema da pergunta por Deus e a sua busca permanece atual, apesar da mudança cultural ocorrida nestas últimas décadas, marcada pela secularização. ${ }^{2}$ Há uma parcela significativa da humanidade que se questiona sobre o problema de Deus e está disposta a percorrer um caminho que conduza ao ato pessoal da fé em um Deus. Aliada a esta questão, brota a pergunta sobre o sentido da vida humana, diante da crescente autonomia vivida pelas pessoas nos dias de hoje, dominada pela supremacia da técnica, pelo pluralismo e pelo relativismo em diversos campos do pensamento e da moral.

O presente artigo visa estudar como o teólogo suíço, Hans Urs von Balthasar - nascido em Lucerna, a 12 de agosto de 1905, e falecido em Basileia, a 26 de junho de 1988 -, apresenta o caminho para a descoberta e a aceitação da existência de Deus como resposta à busca de Deus própria a todo ser humano e, quiçá, realizar um caminho em direção ao ato da fé, e, assim, encontrar um novo sentido para a sua vida. O pensamento do autor encontra-

\footnotetext{
${ }^{1}$ No final de seu livro, C. Dotolo apresenta uma extensa bibliografia sobre o tema (DOTOLO, C., Teologia e postcristianesimo, p. 313-351).

${ }^{2}$ Como exemplo da possibilidade de pensar em Deus em um mundo secular: DALFERTH, I. U., Trascendenza e mondo secolare.
} 
se exposto, de forma detalhada, no volume III - Spiritus Creator ${ }^{3}$ de sua obra, com cinco volumes, intitulada Ensaios Teológicos. ${ }^{4}$

Tal proposta inicia com a abordagem de alguns pressupostos necessários para despertar o interesse por Deus, indicativos de um caminho a ser percorrido por toda pessoa que deseja encontrar um sentido para a própria vida, que ultrapasse o imanentismo material, e chegue a perceber razões abertas pelo amor, como uma nova forma de aceder à realidade e perceber nova perspectiva para si mesmo. O pressuposto fundamental utilizado pelo teólogo estudado aqui é a analogia com o amor maternal, pois é a chave capaz de abrir o ser humano para o caminho de Deus ao possibilitar estabelecer uma relação entre o amor maternal e a descoberta de Deus como amor, na medida em que a relação amorosa entre a mãe e o filho desperta a pessoa para a existência de Deus e sua descoberta como amor.

\section{Dois pressupostos}

Para compreender como Balthasar expõe o caminho percorrido pela pessoa humana para poder encontrar a Deus, é preciso partir de dois pressupostos. O primeiro é a analogia entis e o segundo é o amor maternal. A analogia entis é a base para estabelecer o caminho possível para Deus a partir da analogia do amor da mãe para com o filho.

\subsection{A analogia entis}

A analogia entis em Balthasar ${ }^{5}$ é o conceito de fundo que sustenta a possibilidade de o ser humano encontrar a Deus. Seu raciocínio se sustenta na compreensão de Erich Przyzwara. ${ }^{6}$ Para este estudioso,

\footnotetext{
${ }^{3}$ BALTHASAR, H. U., Ensayos Teológicos. O original alemão é de 1967, publicado pela editora Johannes Verlag, Einsielden.

${ }^{4}$ V.1: Verbum Caro; v.2: Sponsa Verbi; v.3: Spiritus Creator (1967); v.4: Pneuma e Instituição (1974); v.5: Homo creatus est.

${ }^{5}$ Acerca do debate entre Balthasar e Karl Barth sobre a analogia entis, ver GAUTIER, B., Balthasar en Dialogue avec Barth, p. 50-184.

${ }^{6}$ Erich Przywara nasceu a 12 de outubro de 1889, em Kattowitz, e faleceu a 28 de setembro de 1972, em Hagen. Ele foi um sacerdote jesuíta, que se tornou conhecido por defender o princípio metafísico da analogia do ser - analogia entis - como um princípio formal da filosofia e da teologia. Ele dialogou com Karl Barth, que o considerava como o oponente mais sério. Para uma breve biografia, ver BALTHASAR, H. U., Erich Przywara, p. 347-354.
} 
do ponto de vista noético, a analogia entis é a "fórmula que aniquila toda fórmula", o princípio sistemático que quebra os sistemas para lhes ordenar ao mistério divino; do ponto de vista ontológico, a analogia entis é a estrutura do ser, segundo a qual o ser finito só pode entender a si mesmo em um Deus, que é sempre maior. Este é um princípio dinâmico, não estático, que faz compreender o ser como uma "dinâmica original", que é a relação entre o mundo e Deus, o que o torna um princípio formal. ${ }^{7}$ Desse modo, segundo Bruno Gautier, a analogia entis significa relação e se define como "relação de alteridade recíproca", ou seja, a relação entre o ser humano e Deus. ${ }^{8}$

Há três formas de analogia: a primeira, a relação entre Deus e a criação, guiado pelo princípio da maior dissimilitudo, caracterizado como o agir soberano de Deus, imprimindo na criatura uma dinâmica que a impulsiona para Deus; a segunda, a analogia interna à criação, quando a condição das coisas do mundo se caracteriza pelo devir, que se realiza por meio da passagem da potência, que é a dinâmica no sentido de possibilidade, ao ato; a terceira, a analogia entis, que é analogia entre as analogias, a que relê a segunda analogia (interna à criação) e a primeira (entre Deus e a criação). É esta última que Przywara chama de analogia entis, segundo Bruno Gautier, que a explica da seguinte forma: "A ideia é que a criatura vibre ela mesma em um movimento que lhe vem deste ato que Deus fez para ela". ${ }^{9}$ Desse modo, a estrutura da criatura se explica unicamente a partir da sua relação para com Deus, marcada por uma alteridade recíproca.

Para Tomás de Aquino, a criação se compõe de essência e existência e doutrina das causas segundas. Com a doutrina das causas segundas, Tomás consegue conciliar a toda-potência de Deus com a atividade própria da criatura. Przywara, seguindo este pensamento do Aquinate, realiza a unidade entre a imanência e a transcendência divina, pois a criação espelha Deus, que tem em comum a essência e a existência, enquanto que as coisas criadas têm uma desarmonia entre a essência e a existência, o que não existe em Deus, que é a "identidade essencial", ao passo que na criatura é uma "unidade em tensão". ${ }^{10}$ Para ele, a música, na sua constituição formal, é uma boa ilustração da analogia entis como ritmo do ser, pois se

\footnotetext{
${ }^{7}$ PRZYWARA, E., Analogia entis, col. 469-473.

${ }^{8}$ GAUTIER, B., Balthasar en Dialogue avec Barth, p. 89.

${ }^{9}$ GAUTIER, B., Balthasar en Dialogue avec Barth, p. 95.

${ }^{10}$ GAUTIER, B., Balthasar en Dialogue avec Barth, p. 96-98.
} 
torna uma manifestação do mistério do ser ao expressar a percepção de que o mundo está repleto de Deus. ${ }^{11}$

Balthasar usa este princípio para mostrar a possibilidade de a pessoa humana abrir-se totalmente para Deus ao realizar a analogia entre a existência da mãe e de seu amor maternal com a existência de Deus e seu amor para com os seres humanos, como será exposto a seguir.

\subsection{O amor maternal}

A relação de amor entre a mãe e o filho é capaz de provocar a abertura para Deus, pois desperta a consciência de si próprio no filho, o que não é compreensível pela "estrutura formal" da mente, pois o amor maternal é uma impressão sensorial que está no plano da inteligibilidade categorial, que, por sua vez, está "em função de certa capacidade dinâmica para a afirmação do ser simpliciter e a representação do ser concreto e finito" que se tem diante de si mesmo. ${ }^{12}$

A dinâmica é a seguinte: o filho responde com amor ao amor da mãe como resposta ao amor suscitado pela mãe. É uma resposta de amor ao amor, na qual se estabelece uma relação entre o "eu" e o "tu". Embora sejam duas pessoas diferentes - dois "eu" diversos e cada um com sua personalidade própria -, o amor é que possibilita a realização de tal encontro. Balthasar denomina este encontro de "elipse de amor", mesmo sendo o "eu" da mãe diferente do "eu" do filho. E acrescenta que este amor "é o bem supremo e absolutamente suficiente", além do qual não se pode esperar mais nada $a$ priori, “porque neste 'eu-tu' está praticamente iluminada à plenitude da realidade". ${ }^{13}$ Tudo o que segue na vida da pessoa, após esta experiência de encontro, sejam experiências gratificantes ou frustrantes realizadas pelo eu, também em relação ao tu ou ao mundo, tem sua origem exclusiva nesta relação pessoal, que é como uma "centelha originária", uma "irradiação tão nítida e tão pura que implica assim mesmo uma abertura para Deus". ${ }^{14}$

A palavra é o meio de se estabelecer a relação amorosa entre a mãe e o filho, pela qual o "tu" escuta o "eu". Balthasar afirma que no ato de escutar

\footnotetext{
${ }^{11}$ GAUTIER, B., Balthasar en Dialogue avec Barth, p. 99.

${ }^{12}$ BALTHASAR, H. U., Ensayos Teológicos, p. 15.

${ }^{13}$ BALTHASAR, H. U., Ensayos Teológicos, p. 15.

${ }^{14}$ BALTHASAR, H. U., Ensayos Teológicos, p. 15.
} 
está implícita, prévia a toda reflexão, a capacidade de responder. ${ }^{15}$ Quando a mãe interpela o filho por meio de um ato de amor, este só pode responder com uma resposta de amor, pois "o amor desperta amor", assim como o sol faz a vegetação crescer, não podendo, por isso, responder com desamor. ${ }^{16}$

É nesta dinâmica que o filho descobre, além de si mesmo como pessoa, o outro e o mundo. No movimento do "eu" para o "tu", o "eu" se descobre a si mesmo, pois ao dar-se experimenta o "eu me dou", abrindo seu ser para o outro e para o mundo, ou seja, para o que está fora de si mesmo. Balthasar afirma que ao passar de si mesmo para o outro, ao mundo amplo e aberto, o eu "vive e experimenta sua liberdade, sua capacidade cognoscitiva e seu ser espiritual". ${ }^{17}$

Na medida em que a criança responde e corresponde a este processo, se dá conta que o mundo exterior não saiu do seu eu, mas que a realidade é exterior e está ao redor de si como "uma maravilha incompreensível" e percebe que o mundo exterior existe graças ao tu e não ao eu pessoal, nunca encontrando em si mesmo um fundamento suficiente a priori. Para Balthasar, portanto, "o espaço e o mundo não existem pela graça do eu, senão pela graça do tu". ${ }^{18} \mathrm{O}$ eu pode pisar o solo da realidade e resguardar a distância até o outro por uma graça original que lhe é concedida. ${ }^{19}$

Tal resposta só é possível no amor, pois o amor apela a uma resposta. E a resposta só é possível com a totalidade, a centralidade e a plenitude da pessoa - do eu -, que deve abrir mão do melhor de si para corresponder a este chamado. $\mathrm{O}$ amor maternal apela para a totalidade da pessoa e, desta forma, o filho responde com a consciência de que a resposta só pode ser dada na integralidade do seu ser pessoal, pois a mãe ama totalmente o eu pessoal do filho e não as suas propriedades. É o que afirma Balthasar:

Este sentir-se inteiramente interpelado constitui a maior dita do amor, não tanto porque $o$ apelo da mãe diga algo ao filho, mas porque a individualidade deste, mais além do conjunto de suas propriedades, seu próprio eu tal qual,

\footnotetext{
${ }^{15}$ BALTHASAR, H. U., Ensayos Teológicos, p. 15-16.

${ }^{16}$ BALTHASAR, H. U., Ensayos Teológicos, p. 16.

${ }^{17}$ BALTHASAR, H. U., Ensayos Teológicos, p. 16.

${ }^{18}$ BALTHASAR, H. U., Ensayos Teológicos, p. 16.

${ }^{19} \mathrm{O}$ contrário disto, segundo Balthasar, é "a elipse se converter em círculo; o mundo, o amor e o conhecimento colidiriam de repente; o ser se confundiria com o parecer e o conteúdo pleno com a lei vazia; e, no melhor dos casos, o amor se tornaria mero instinto e o conhecimento simples função" (BALTHASAR, H. U., Ensayos Teológicos, p. 16).
} 
experimenta isto ao mesmo tempo: o meu eu é amado, é digno de amor por parte da minha mãe, e a minha resposta não pode consistir mais do que a entrega deste eu - com tudo o que isto possa acarretar e que já não necessitamos saber de maneira particularizada -. As crianças pequenas se lançam ao nosso regaço como se fossem uma bola. ${ }^{20}$

\section{O caminho para Deus}

A partir destes dois pressupostos, Balthasar expõe o caminho para Deus por meio de três passos consequentes: primeiro, a descoberta do tu humano abre caminho para chegar ao Tu divino, para, em segundo lugar, perguntar sobre a questão de qual Deus é este, e, por fim, refletir sobre a relação entre a natureza humana e a necessidade da graça divina.

\subsection{Do tu humano ao Tu divino}

O processo explicado no ponto anterior - os dois pressupostos - abre a possibilidade de acontecer a passagem do amor maternal para a descoberta de um outro diferente de si mesmo e do mundo: a existência de Deus como amor. Isto acontece como um passo posterior à descoberta do amor maternal.

Balthasar afirma ser necessário que o filho distinga, a partir da experiência pessoal do amor da mãe, entre amor ao próximo e amor ao absoluto. Este processo compete aos pais, pois são eles quem devem procurar fazer com que o amor do filho descubra a Deus. E o teólogo suíço considera que este processo é mais fácil quando os pais se manifestam e agem como filhos de Deus e se orientam, juntamente com seus filhos, a Deus. ${ }^{21}$ Desse modo, não é necessário desmistificar o amor incondicional entre pais e filhos e reduzi-lo ao horizonte terreno, pois é justamente este amor entre pais e filhos que funda e mantém de pé o amor a Deus, e que sucessivamente remeterá ao Tu absoluto. E é possível que mesmo nas relações com o próximo se entreveja o mistério do amor ao Absoluto.

Para Balthasar, somente no cristianismo é possível fazer a passagem do amor maternal para o amor de Deus. Por isso, ele quer deixar claro, de forma contundente, que a explicação cristã é a única plenamente satisfatória sobre o que está subjacente na primeira experiência de espírito adulto: o ser

\footnotetext{
${ }^{20}$ BALTHASAR, H. U., Ensayos Teológicos, p. 16.

${ }^{21}$ BALTHASAR, H. U., Ensayos Teológicos, p. 17.
} 
e o amor são coextensivos. ${ }^{22}$ Ele faz esta afirmação compreendendo que esta experiência só é possível para um ser cujo núcleo é o espiritual. Para tal, ele se fundamenta em Tomás de Aquino, que denomina este processo de reflexio completa, isto é, a capacidade de captar plenamente o eu ao ultrapassar-se para ir a um tu reconhecido como o outro, e que ama, ${ }^{23}$ diferentemente do animal, que é incapaz de chegar a esta representação do ato espiritual, pois que abrange a inteligência e a vontade próprias do ser humano. ${ }^{24}$ Assim como o ser está totalmente despojado de si mesmo para o reconhecimento espiritual, deverá estar também no horizonte do valor, do bem e do amor, mesmo que as decepções e deficiências possam ofuscar este horizonte próprio do ser humano e deixá-lo desnudo como "simples ser" (esse nudum). Estas experiências, todavia, lançam a pessoa para um horizonte futuro. ${ }^{25}$

Aceitar a unidade original "entre o ser e o bem, a realidade e o amor" leva a considerar que "não basta dizer que todo o conhecimento terreno é determinado pela diferença constitutiva e intransponível entre o ser e essência". ${ }^{26}$ Esta diferença adquire um significado ulterior fundamental: de um lado, a existente entre o domínio racional e ético das situações do ser terreno, e, de outro lado, o da consciência de um poder ser que nunca poderá ser dominado nem alcançado, diante de uma acolhida gratuita no âmbito total do ser. Esta consciência acompanha a experiência primordial de que, através do apelo a partir de fora do próprio eu, se chega a participação em uma comunidade universal dos seres. Balthasar afirma não ter importância que a mãe, de onde partiu o chamado primordial, também é chamada do mesmo modo, assim como todos os seres humanos são igualmente chamados, visto ninguém poder chegar pela própria plenitude de poderes à "mesa do existir", onde, qual uma sala de banquete, todos entram com reverência, com a respiração contida, mas logo se "sentam entre os demais como em sua própria casa". ${ }^{27}$

Ao participar da comum "mesa do existir", a pessoa poderá se colocar a pergunta sobre o seu estar no mundo ao constatar o caráter aleatório de

\footnotetext{
${ }^{22}$ BALTHASAR, H. U., Ensayos Teológicos, p. 17.

${ }^{23}$ De veritate $22,2 \mathrm{c}$ ad 1 , ad 2.

${ }^{24}$ BALTHASAR, H. U., Ensayos Teológicos, p. 17.

${ }^{25}$ BALTHASAR, H. U., Ensayos Teológicos, p. 18.

${ }^{26}$ Balthasar observa que os termos "ser" e "essência" devem ser considerados no sentido tomista e que Platão entende a ideia de bem como o sol do ser, que só pode ser percebido pelo olho deslumbrado do espírito em flashes repentinos (BALTHASAR, H. U., Ensayos Teológicos, p. 18).

${ }^{27}$ BALTHASAR, H. U., Ensayos Teológicos, p. 18.
} 
sua existência face aos outros. Todavia, Balthasar considera esta questão como uma oportunidade imperdível, pois provoca a pergunta pelo sentido de própria existência e do estar no mundo, que, embora compartilhando com todo o ser humano a mesma situação no mundo, o faz distinguir dos demais indivíduos, ou ao ser comum, pela pergunta que se faz. É que, "para o indivíduo, é sempre uma advertência salutar pensar na natureza aleatória de sua procriação", embora este pensamento possa ser insuportável e possa levar a pessoa ao cinismo e ao desespero, mesmo provocando a reflexão sobre o seu estar no mundo. Mas, para quem tem uma ideia do Deus vivo, segundo Balthasar, conseguirá pensar seu ser pessoal como algo criado diretamente por Ele e entenderá a misteriosa concatenação com os "atos procriadores fortuitos da natureza" e entenderá a sua existência de forma inteiramente nova. Deus quer criar, mas mão de maneira absoluta, porque quis vincular sua própria ação criadora a "causas concomitantemente obscuras e cegas", ${ }^{28}$ isto é, a vontade humana. ${ }^{29}$

O ser humano compartilha com toda a criação, como a dos animais, a morte, pois todo ser, baseado na experiência cotidiana, "produzido por geração é destinado à morte de antemão", ${ }^{30}$ pois ela é a contrapartida do nascimento. Daí surge a pergunta sobre a morte: o que significa a morte para um ser espiritual que vem de Deus e vai para ele, mas que se reconhece cidadão deste mundo natural? ${ }^{31}$ Esta questão, para Balthasar, desperta o interesse por uma lei básica da existência humana: o espaço. O ser humano vive no mundo. No ser humano, o espaço abarca a matéria, isto é, o vital e o biológico, que está sujeito às leis da estatística e da evolução, que ordenam o ser humano em meio ao todo (totum) da natureza.

Ao mesmo tempo, o ser humano, diante de sua própria fragilidade, sente que não é o fundamento de seu espírito, a sua causa eficiente.

\footnotetext{
${ }^{28}$ BALTHASAR, H. U., Ensayos Teológicos, p. 19. Si, em 24 de maio de 2015).

${ }^{30}$ BALTHASAR, H. U., Ensayos Teológicos, p. 19.

${ }^{31}$ BALTHASAR, H. U., Ensayos Teológicos, p. 19.
}

${ }^{29}$ BALTHASAR, H. U., Ensayos Teológicos, p. 18-19. É interessante considerar aqui a questão atual do debate em torno do aborto e também sobre a ecologia, no sentido de respeito à criação. Todavia, nem sempre os argumentos válidos em defesa da natureza são considerados conclusivos em relação ao aborto. A Igreja Católica defende a iliceidade do aborto assim como sua descriminalização. O Papa João Paulo II expõe a doutrina do magistério da Igreja a respeito do aborto na Encíclica Evangeliium Vitae, n. 58-63, denominando-o como crime "grave e abjurável" (EV 58). O Papa Francisco, na Encíclica Laudato Sì, apresenta a posição atual da Igreja sobre a ecologia, procurando conscientizar sobre a importância do cuidado com o planeta, a "casa comum", e o clima como um bem comum (PAPA FRANCISCO, PP., Encíclica Laudato 
Assim, concomitante ao espaço, encontra-se a abertura de seu espírito ao um espírito superior, ao qual Balthasar denomina de Deus. Assim, o ser humano, graças ao seu espírito, está imediatamente relacionado a Deus, independentemente de seu estado de evolução e das leis da natureza, que não se sobrepõem a dinâmica própria do espírito, mesmo diante da possibilidade do progresso técnico. Desse modo, ainda seguindo o pensamento de Balthasar, se realiza o encontro do ser humano espiritual com Deus, um espírito superior, abrindo a perspectiva do absoluto e a consciência de que nada neste mundo pode conduzir a salvação absoluta, apesar da natureza infra-espiritual só possa realizar-se no espírito absoluto e, esta situação, comporta a promessa de que toda a busca mundana e existencial realizar-se-á, um dia, no encontro definitivo com o amor, ou seja, com a salvação oferecida por Deus. ${ }^{32}$

A partir desse modo de pensar, Balthasar entende como tema consequente a pergunta sobre Deus. Qual Deus sustenta a promessa de amor e seja capaz de levá-lo à sua plenitude? As perguntas se justificam a partir da constatação de que se percebe o oposto ao amor, como o ódio, a guerra - só para citar algumas situações -, presente na história humana. E ele responde a estas perguntas examinando a dialética da ideia de Deus.

\subsection{A dialética da ideia do Tu absoluto e a descoberta de Deus cristão como amor}

A pergunta sobre Deus se impõe justamente pelo raciocínio exposto até aqui. A qual Deus se tem acesso? A história da humanidade mostra as muitas tentativas de resposta à esta pergunta. A resposta exige pesquisar, segundo Balthasar, as várias tentativas de resposta, dadas a partir de perspectivas diferentes, como é o caso dos mitos e das diversas filosofias, que expõem um conceito de Deus bem específico. É assim que se estabelece uma verdadeira dialética da ideia de Deus. Todavia, para Balthasar, o cristianismo oferece a possibilidade de pensar a Deus não de acordo com uma ideia geral, simplesmente como um ente cultural, mas a partir de uma novidade só possível de ser descoberta e apresentada pelo cristianismo.

Uma primeira ideia de Deus é dada pelos mitos. É o derivado religioso da experiência originária da solidariedade com o próximo, mesclado pelos sentimentos existenciais que o homem experimenta ante o mistério e o poder

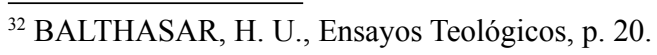


absoluto da natureza, como as catástrofes naturais, a luz, o fogo e a força incontrolável da natureza, e do ser em sua totalidade, que pode, até, gerar pânico diante das forças incontroláveis da natureza. Por detrás destas forças, se manifesta um "tu" do qual o ser humano pode pedir favores ou aplacar a ira. Esta situação provoca a descoberta de um Deus "para mim", misterioso e indefinível, que pode garantir favores, proteção e ajuda, e que faz recordar a primeira experiência infantil para com a mãe, quando a criança se entrega incondicionalmente ao amor maternal, mas, ao mesmo tempo, percebe que a sua proteção não pode ser plenamente garantida pelos pais e pelas demais pessoas na sua totalidade.

Desta constatação, Balthasar conclui que, independente dos diferentes nomes com que Deus possa ser denominado, este Deus é entendido "de maneira não reflexa" pela criança como alguém, um uno, "igual à mãe, ao pai, ao amigo e o companheiro da mesma tribo", e que não representam nada "para mim". Na medida em que reflete, a criança realiza a passagem do Deus "para mim" para o Deus e constata que esta é a sua propriedade mais importante: Ele é uma pessoa, dotado de poder e liberdade de uma pessoa, se inclina para o homem, que necessita dele e se orienta até Ele e assente em anunciar o seu amor, sua proteção e atender seus pedidos.

A consequente adoração, oração e sua capacitação mediante o sacrifício pessoal, como expressão sensível da disposição de abandonar-se em Deus, dá continuidade ao ato de amor da criança para com a mãe, em um amor que responde e se entrega. Este Deus será sempre um ser único, especial, que se inclina para a pessoa humana e que a envolve em um círculo protetor e a faz sentir-se protegida, escutada e salva. ${ }^{33}$

Como exemplo, Balthasar cita o mito de Homero, com a deusa Atena, e dos deuses gregos, com Ra, e os da Babilônia, entre os quais, Marduk. Todavia, para a justa compreensão de Javé, de acordo com a Bíblia, segundo o teólogo suíço, ele não se apresenta como aquele que corresponde a ideia abstrata e universal da divindade, mas, em primeiro lugar, é o "Deus de ...", assim como seu povo escolhido, Israel, é "um povo para ...", e, em segundo lugar, aceita a rivalidade com os demais deuses, pois, a partir de uma visão ampla da história, ele é sempre vencedor, o verdadeiro Todo Poderoso, diante do qual os outros deuses são um "nada". ${ }^{4}$

\footnotetext{
${ }^{33}$ BALTHASAR, H. U., Ensayos Teológicos, p. 22.

${ }^{34}$ BALTHASAR, H. U., Ensayos Teológicos, p. 23.
} 
Uma segunda ideia de Deus é dada pela filosofia, que supera os mitos pelo raciocínio crítico. O surgimento e o desenvolvimento da ideia de Deus, fundamentalmente dualista, pois constituída por um mundo de deuses imortais e outro de homens mortais, foi superada pela reflexão sobre a essência divina, que mostra, em primeiro lugar, um deus sem fundamento e sem condicionamentos, pois ele é o fundamento do mundo. Balthasar cita Platão, que concebe deus como o bem e o sol radiante, aquele que pode fundamentar todas as coisas; no mito de Timeo, ele não pode ser apresentado como amor pessoal; e no do Banquete, o amor é possível apenas por parte do ser humano, que busca a deus, e da parte do mundo, onde o Eros mantem arrebatado em direção ao absoluto e em constante movimento. Desta forma de pensar, se extrai seu corolário: o absoluto não pode ter nenhum contrário. Todavia, constata Blathasar, o mundo está cheio de contrários, e o próprio ser humano, enquanto finito, tem seu contrário, que é Deus. Por isso, para resolver tal impasse, Balthasar recorre ao non-Aliud (o não-outro) de Nicolau de Cusa, ${ }^{35}$ para afirmar que Deus não tem contrário, pois ele é o não-Outro. Por isso, Balthasar mostra que o "divino-absoluto", que não pode deixar de ser o objeto e a meta da aspiração religiosa da pessoa humana, se oculta no indivisível, na intimidade de um tu: é o amado, ao que se deve atribuir todo o bem, mas que permanece apessoal, livre de todo limite do "eu-tu", de tal modo que só o alcança quem não leva em conta o limite de seu ser pessoal e vai ao encontro daquele que não tem contrário. ${ }^{36}$

Diante disso, Balthasar conclui que a ideia do que a humanidade tem de Deus é incompleta, pois não pode existir uma religião puramente filosófica ou civil. Estas se apoiam no mítico ou em uma ideia meramente abstrata de Deus, visto que a ideia de Deus desenvolvida pelos mitos e pelas filosofias são incompletas. A religião civil, como quereria a filosofia, não pode existir, pois não se apoia nem no amor nem na entrega pessoal. ${ }^{37}$

\footnotetext{
${ }^{35}$ Nicolau de Cusa ou Nicolau Krebs ou Chrypffs (Cusa, Tréveris, Alemanha, 1401 - Todi, Úmbria, Itália, 11 de agosto de 1464) foi um cardeal da Igreja Católica Romana, um dos primeiros filósofos do humanismo renascentista, e autor de inúmeras obras, sendo a principal delas Da Douta Ignorância, publicada em 1440.

${ }^{36}$ Aqui Balthasar concorda com Karl Barth, pois considera que este acerta ao constatar existir uma virada invevitável "para o ateísmo nas alturas subtis da mística filosófica". E continua afirmando: "o sem conteúdo-absoluto se converte em forma lógica (Hegel), em lei processual (Marx) e o peso pesado recai sobre o amor inter-humano quase divino (Feuerbach)" (BALTHASAR, H. U., Ensayos Teológicos, p. 24).

${ }^{37}$ BALTHASAR, H. U., Ensayos Teológicos, p. 25.
} 
Porém, o cristianismo não pode prescindir das duas anteriores e tampouco completá-las.

Aideia cristã de Deus difere das anteriores. Para mostrar como o cristianismo tem o conceito próprio de Deus, Balthasar entende que o cristianismo tem como ponto de partida a analogia entre o chamado e a resposta de amor, o que constitui para ele em um "postulado apriorístico" sobre a formação da religião, que poderia ser descrito da seguinte forma: existe uma dialética entre o coração e a razão, que parece abolir qualquer forma estabelecida. O coração exige um Deus como um Tu e um amor absoluto entre ambos, enquanto a razão não permite entender a Deus como um Tu, pois Deus deve ser absoluto, se situando, assim, além de qualquer "tensão de contrários" e deve ser entendido como a bondade universal, necessariamente anônima, e não como um ser pessoal que fala pessoalmente e que suscita um encontro pessoal. ${ }^{38}$

Para resolver esta tensão, Balthasar recorre ao Deus de Israel e afirma que com seu primeiro ato salvífico histórico, que é a eleição do povo de Israel, ele põe as bases para a unidade da ideia de Deus que o ser humano se esforça em vão para captar: "Deus se mostra poderoso e bom ao escolher um Povo", conforme Dt 4,34 e 7,6. Através do chamado e do resgate seletivo do Egito, Deus se torna sujeito e sócio de Israel, povo a quem falta méritos e atributos para tal eleição, conforme Dt 7,7 e 8,17. O motivo da eleição é um amor gratuito (Dt 7,7.9), que só pode ser respondido com um amor total e ilimitado (Dt 6,5). Trata-se, portanto, de um acontecimento único em seu gênero, como expressa muito bem a oração de Davi: "Como o teu povo Israel, há outro povo na terra a quem um Deus tivesse ido resgatar para fazer dele o seu povo, para o tornar famoso e realizar em seu favor tão grandes e terríveis coisas, expulsando de diante do seu povo nações e deuses?" (2Sm 7,23). A partir desta eleição, que é gratuita e única, fruto do amor total e incondicional da parte de Deus, transparece a onipotência de Deus e ele se revela como o Deus único. Seguindo Is 43,10-12, o caráter absoluto de seu amor revela o caráter absoluto de seu ser:

É actus purus amoris no momento originário em que o homem é elevado mediante o puro "eu-tu" à categoria de ser pessoal; realiza o que só a mãe pode fazer em alguns momentos - e, para os outros, só prometer - pois entra imediatamente, junto com seu filho, na mesma categoria de todos os seres necessitados de amor absoluto. ${ }^{39}$

\footnotetext{
${ }^{38}$ BALTHASAR, H. U., Ensayos Teológicos, p. 25.

${ }^{39}$ BALTHASAR, H. U., Ensayos Teológicos, p. 26.
} 
Todavia, esta constatação pode produzir uma nova dialética: como uma criatura finita pode resistir a um amor e a uma exigência de amor absolutos? Balthasar entende que esta dialética faz parte da modalidade da própria relação do amor, porquanto fica claro que a revelação bíblica do amor divino só pode falar de modo dialético: de modo indicativo, pois Deus não se arrepende de sua eleição, de um lado, e de modo condicional, de outro, pois a aliança bilateral selada no Sinai repousa na unilateralidade da aliança selada com Noé, com Abraão e até com Jesus Cristo, permanecendo assim até o fim da Nova Aliança, pois Deus é ao mesmo tempo tanto uma realidade "infinitamente única e determinada" quanto "absolutamente universal": Deus é Ele e nenhum Outro. ${ }^{40}$

Um novo problema desponta diante da consideração do amor absoluto de Deus para com o ser humano: como pode haver uma comunidade de amor entre Deus e a pessoa humana diante da constatação de que as pessoas são tão distintas e não compartilham da mesma natureza? Não é antinatural tal relação, que exigiria uma natureza igual como condição para acontecer esta relação de amor, como a existente entre a mão e o filho, que compartilham a mesma natureza ${ }^{41}$ Tais questionamentos abrem a possibilidade da reflexão sobre a natureza e a graça, exposta a seguir, além de esclarecer ainda mais a estrutura do conhecimento de Deus.

\subsection{A relação entre a natureza e a graça}

Balthasar defende a ação simultânea entre a natureza e a graça no processo de descoberta de Deus, apesar de haver entre ambas ao mesmo tempo uma diferença e uma continuidade. A natureza e a graça se encontram em dois planos diferentes: há o ato criador de Deus (a natureza) e a descoberta de Deus (a graça), com uma diferença cronológica que determina a diferença; a continuidade é estabelecida pela solidariedade humana. ${ }^{42} \mathrm{O}$ ser humano é

\footnotetext{
${ }^{40}$ BALTHASAR, H. U., Ensayos Teológicos, p. 27. Os nomes de Deus que ajuda por amor podem ser diversos nas diferentes culturas e povos e épocas; todavia, "Deus é sempre esse ser único, especial, que se inclina até mim, em cujo círculo protetor eu me sinto protegido, escutado e salvo" (BALTHASAR, H. U., Ensayos Teológicos, p. 22). Como exemplo, Balthasar cita os deuses protetores dos heróis em Homero: Atena é a deusa de Ulisses; Zeus é o deus capaz de manter a ordem e que ajuda os demais deuses dentro de seu plano providencial secreto. No Egito, Ra é um deus onipotente e sempre disposto a ajudar o país (BALTHASAR, H. U., Ensayos Teológicos, p. 22-23).

${ }^{41}$ BALTHASAR, H. U., Ensayos Teológicos, p. 27.

${ }^{42}$ BALTHASAR, H. U., Ensayos Teológicos, p. 34.
} 
capaz de descobrir a Deus, mesmo existindo diferença entre a natureza humana e a natureza divina, pois Deus, ser divino, se abre para a pessoa, ser humano, a partir das possibilidades inerentes à própria condição humana.

Para perfazer este caminho de encontro entre Deus e a pessoa, Balthasar apela, novamente, para o amor maternal e para o amor filial. O encontro entre o amor da mãe e o amor ao filho e do filho para a mãe tem algo de definitivo e, ao mesmo tempo, algo temporal e representativo. Simultaneamente a mãe sabe que gerou o filho, e, por isso, o sentimento de pertença em relação ao filho, mas, ao mesmo tempo, percebe que ele é distinto de si mesma, pois ela está diante de uma "maravilha incompreensível", que só pode ser fruto da obra de Deus. ${ }^{43}$ Esta relação faz compreender a ação da natureza e da graça para a descoberta de Deus.

Assim, Balthasar entende a natureza humana como uma "natureza criada", ${ }^{44}$ a partir da percepção da mãe de que está diante de alguém diferente dela, um mistério insondável, ou seja, o seu filho é um ser próprio, que ultrapassa o seu ato criador materno. Deus é quem criou seu filho: ele tem uma natureza criada. E é à luz desta experiência materna que Balthasar vê a possibilidade do ser humano chegar ao conhecimento de Deus, pois assim a mãe desperta o ser espiritual no filho.

Quanto ao tema do conhecimento de Deus, Balthasar discorda de três teorias, a saber: a primeira é a ideia inata de Deus, de Boécio, quando ensina que cada ser humano apenas necessita despertar no próprio intelecto a ideia de Deus mediante a experiência de sentir-se protegido enquanto id quo maius cogitari nequit; a segunda é o chamado tradicionalismo, de Bonald e Bonnetty, a partir da qual o homem só pode chegar a Deus pela revelação; ${ }^{45}$ a terceira é o ontologismo, de Gioberti, segundo o qual o primeiro que se conhece não é o ser finito, senão o infinito e o divino. ${ }^{46}$ Ele argumenta que a presença da mãe desperta no filho a realidade de seu próprio ser espiritual, pois lhe abre o horizonte do ser e do amor, não lhe possibilitando ver a Deus imediatamente, mas apenas "um fulgor de sua presença" mediante o dom da promessa de

${ }^{43}$ BALTHASAR, H. U., Ensayos Teológicos, p. 28.

${ }^{44}$ BALTHASAR, H. U., Ensayos Teológicos, p. 34.

${ }^{45}$ As teses relativas ao fideísmo e ao tradicionalismo, como também a retratação de Louis Eugène Bautain, encontram-se em DH 2751-2756. A tese contra o tradicionalismo de Augustin Bonnetty encontra-se em DH 2811-2814.

${ }^{46}$ BALTHASAR, H. U., Ensayos Teológicos, p. 29. Os erros dos ontologistas foram condenados por um Decreto do Santo Ofício de 18 de setembro de 1861 , que se encontra em DH 2841-2847. 
graça e de amor absolutos. É como um "conhecimento primordial”, como um "relâmpago", que o homem recebe de Deus. ${ }^{47}$ Este modo de pensar está de acordo com as conhecidas cinco vias de acesso a Deus ensinadas por Tomás de Aquino. ${ }^{48}$

O mesmo acontece com o Concílio Ecumênico Vaticano I quando afirma que Deus, "como princípio e fim de todas as coisas, pode ser conhecido com certeza pela luz natural da razão humana a partir das coisas criadas" ${ }^{49} \mathrm{O}$ Vaticano I entende esta afirmação como uma possibilidade real, porquanto o horizonte do ser humano está tão aberto ao conhecimento e a vontade que formalmente inclui o próprio ser criado e a ideia do criador, pois o ser humano está ordenado para um fim sobrenatural por causa da infinita bondade de Deus. ${ }^{50}$

É uma possibilidade real, porque o horizonte aberto por Deus pode ser materialmente desfigurado pelo pecado, aparecendo, entre outras formas, como egoísmo, egocentrismo, orgulho, vaidade, assim como muitas crianças são expostas tanto ao mal moral quanto físico em suas famílias. Assim, Deus vem em socorro do ser humano. ${ }^{51}$

Desse modo fica clara a distinção entre a natureza e a graça, como também a continuidade entre ambas, fruto da solidariedade humana, na qual transparece o ser humano como ser espiritual chamado e capacitado a dar resposta. É esta condição de ser chamado e responder que o torna um ser espiritual. ${ }^{52} \mathrm{O}$ sorriso da mãe é a primeira linguagem de amor que o filho entende e é o ponto de partida para o início de uma cadeia de relações com outras pessoas, que se expressa pela realidade da palavra, que sucede ao aprendizado da linguagem conexa. ${ }^{53}$

A ação da graça de Deus na existência de toda pessoa se dá pela possibilidade do chamado de Deus ser dirigido à pessoa humana. Balthasar entende tanto o chamado de Deus como essencial para o ser humano quanto à capacidade do ser humano para responder, ${ }^{54}$ pois a capacidade do ser humano de ser chamado por Deus é algo intrínseco à sua natureza, é uma potentia

\footnotetext{
${ }^{47}$ BALTHASAR, H. U., Ensayos Teológicos, p. 29.

48 ST I, I-II, q. 109-203.

${ }^{49} \mathrm{DH} 3004$.

${ }^{50}$ DH 3005.

${ }^{51}$ BALTHASAR, H. U., Ensayos Teológicos, p. 32-33.

${ }^{52}$ BALTHASAR, H. U., Ensayos Teológicos, p. 34.

${ }^{53}$ BALTHASAR, H. U., Ensayos Teológicos, p. 35.

${ }^{54}$ BALTHASAR, H. U., Ensayos Teológicos, p. 35.
} 
naturalis passiva. A palavra potência deve ser entendida como um "poder ser", um "ser-já-em-ato", pois o "ser" do filho não foi criado pela sua mãe, mas é despertado após um período de latência. A capacidade intelectual da pessoa está sempre ativa - intellectus semper agens -, mesmo se esta atividade acontece apenas mediante o chamado do mundo como conhecimento atual intellectus possibilis. ${ }^{55} \mathrm{O}$ ser humano é capaz de perceber o chamado de Deus, que não procede de nenhuma ordem da natureza criada, mas das "profundezas do eterno e do absoluto, mas só a graciosa palavra de Deus o dota com a graça da resposta". É a potentia oboedientialis, que tornará a pessoa capaz de responder e obedecer a Deus independente de suas condições. É a graça de Deus agindo no ser da pessoa humana. Para Balthasar, a potentia oboedientialis pressupõe uma potentia naturalis passiva "enquanto deve existir a essência intelectiva criada para que Deus possa mostrar os atos maravilhosos de sua graça". ${ }^{56}$ Assim, Deus se manifesta como o totalmente Outro, cujo ser se contrapõe a essência condicionada de toda criatura como o per se absoluto. Tudo isto demonstra uma sensibilidade para o espiritual por parte da pessoa.

Deus se manifesta para o ser humano sempre de forma humana, mesmo permanecendo a maior dissimilitudo, ${ }^{57}$ ou seja, por meio de palavras, obras e sinais para que ele possa entender. Para evitar mal-entendidos da parte do ser humano, criando uma falsa ideia de Deus, Balthasar entende que a graça divina vem em socorro da pessoa e evita tanto a humanização quanto a mundanização da ideia de Deus. Ele entende a graça à luz de $1 \mathrm{Pd} 2,1-4$, isto é, como a participação na natureza divina, "como a possibilidade de a pessoa ser admitida à esfera do ser divino, para que, sobre a base de um ser e pensar comum (con-naturalitas), se possa instaurar uma relação de intercâmbio pessoal". ${ }^{58}$ Aqui está também presente a analogia entis: não se pode falar de uma divinização direta da pessoa humana, pois Deus está acima de qualquer existente, para que ele "seja tudo em todos", conforme 1Cor 15,28. E ele conclui, a respeito do conhecimento de Deus e de sua revelação, que a manifestação de Deus só pode ser reconhecida pelo ser humano em virtude do dom prévio de sua graça e só apoiado neste dom é que pode responder a Deus. E conclui que esta afirmação vale para a revelação tanto para a que acontece no profundo do coração humano quanto para aquela feita no espaço

\footnotetext{
${ }^{55}$ BALTHASAR, H. U., Ensayos Teológicos, p. 35.

${ }^{56}$ BALTHASAR, H. U., Ensayos Teológicos, p. 36.

${ }^{57} \mathrm{DH} 806$.

${ }^{58}$ BALTHASAR, H. U., Ensayos Teológicos, p. 37.
} 
exterior da história humana. ${ }^{59} \mathrm{E}$ para interpretar a forma da revelação de Deus é preciso "os olhos da fé", de acordo com At 17,27 e Ef 1,18, usando a expressão cunhada por Pierre Rousselot. ${ }^{60}$

Há, assim, uma revelação natural, presente na reflexão sobre a criação de Deus, e uma revelação sobrenatural, na qual a graça de Deus age sobre a natureza, propiciando a pessoa abrir-se para Deus e seu amor eterno, cada vez maior e incompreensível. A graça vem em auxílio da natureza, de acordo com At 17,27 e Ef 1,8. É o amor eterno de Deus agindo no coração de toda pessoa humana. ${ }^{61}$

A pessoa pode conhecer a Deus por meio da revelação de seu amor em Jesus Cristo, por meio do qual se tem acesso ao amor de Deus Pai. É como expressa o apóstolo Paulo: "e conhecer o amor de Cristo, que excede todo conhecimento, para que sejais plenificados com toda a plenitude de Deus" (Ef 3,19 ). A pessoa humana pode ter acesso pela razão à revelação de Deus de forma verdadeira e compreensível, porque Jesus Cristo é a suma revelação do amor de Deus, que se torna presente na história humana por meio da encarnação do Verbo. Só assim é possível a revelação de Deus. Por isso, Balthasar considera a cruz como a grande manifestação do amor de Deus. ${ }^{62}$ Os sinais de Deus se agrupam no espaço histórico, como que tornando visível o mistério de Deus, e tornam possível o conhecimento de Deus, embora continuem sendo incompreensíveis para o ser humano. Não basta uma teologia negativa apofática - para referir-se ao mistério de Deus, mas é preciso também uma teologia positiva - catafática - cujo acento está na graça de Deus, ou seja, em uma incompreensibilidade positiva de Deus: mesmo que Deus esteja acima de tudo e de todos, ele se dignou rebaixar-se até a criatura humana, amá-la e venerá-la com um amor tão grande que foi capaz de encarnar-se. O Verbo que se fez carne (Jo 1,14) é a manifestação da glória de Deus entre os seres

\footnotetext{
${ }^{59}$ BALTHASAR, H. U., Ensayos Teológicos, p. 37.

${ }^{61}$ BALTHASAR, H. U., Ensayos Teológicos, p. 37.

${ }^{62}$ BALTHASAR, H. U., Ensayos Teológicos, p. 38.
}

${ }^{60}$ O jesuíta Pierre Rousselot (1895-1915), professor de teologia dogmática no Instituto Católico de Paris, sugeriu um novo conceito de revelação: que a revelação seja concebida não como uma soma total de verdades, proposições, julgamentos distintos, mas como um tipo de conhecimento que é indefinidamente palpável (mononável) em ideias e proposições distintas que explicitam sem poder esgotá-lo e sem alegar complementá-lo. Apocalipse, ele propôs, era o conhecimento vivo e amoroso que os apóstolos tinham de Jesus. O modo em que os muitos dogmas são contidos no único conhecimento imutável que é o depósito apostólico não é lógico, mas cristológico. A contribuição de De Lubac à questão do desenvolvimento doutrinário é, em grande parte, uma reafirmação da de Rousselot, cujos artigos ele estudou e publicou. 
humanos, que a partir de então se tornam capazes de acessar ao amor de Deus Pai por meio da cruz de seu filho Jesus Cristo. ${ }^{63}$ E só é possível chegar a esta compreensão por causa da ação do dom do Espírito Santo, que age na pessoa na medida em que ela se abre de maneira viva e amorosa "ao espírito divino da amorosa e eterna comunidade do nós". ${ }^{64} \mathrm{O}$ amor das criaturas é um eco posterior ao acontecer primordial e dada graciosamente ao mundo por Deus trindade e, assim, uma participação neste amor de Deus. ${ }^{65}$

Para justificar este processo de conhecimento de Deus, Balthasar novamente lembra a analogia entis, como ponto de partida: o apelo do amor materno é o primeiro ato avivador no núcleo mais íntimo do filho e a sua resposta dota o filho de um eu próprio e o situa no mundo. Esta conduta não é "acidental concreta", mas é a "constituição da substância do sujeito pessoal". O amor torna-se, desta forma, a essência do ser humano e não o acréscimo de uma propriedade. ${ }^{66}$ É a abertura do caminho para a descoberta do amor de Deus: "E isto não como um abstractum nem como um coletivo, mas como algo pessoal difícil de captar: o Deus único (Pai) me (nos) doa o seu 'Filho único' para realizar-me (nos) interiormente com seu Espírito Santo de amor". ${ }^{67}$ Todavia, a resposta do ser humano para Deus só é possível como plena disponibilidade para Deus, como uma "indiferença positiva", que significa a oferta alegre e a entrega pessoal de si mesmo a Deus, por meio da qual a pessoa se dá toda a Deus e cumpre o que Ele exige. Isto só é possível por meio da fé, esperança e caridade. ${ }^{68}$

\section{Em diálogo com as cinco vias de São Tomás de Aquino}

O caminho indicado por Balthasar para chegar a Deus a partir da experiência do amor materno insere-se no debate sobre a cognoscibilidade de Deus dentro da tradição filosófico-teológica ocidental. Não é objetivo aqui apresentar este longo debate. ${ }^{69}$ Quer-se apenas confrontar o caminho apresentado

\footnotetext{
${ }^{63}$ BALTHASAR, H. U., Ensayos Teológicos, p. 38.

${ }^{64}$ BALTHASAR, H. U., Ensayos Teológicos, p. 39.

${ }^{65}$ BALTHASAR, H. U., Ensayos Teológicos, p. 39.

${ }^{66}$ BALTHASAR, H. U., Ensayos Teológicos, p. 39-40.

${ }^{67}$ BALTHASAR, H. U., Ensayos Teológicos, p. 40.

${ }^{68}$ BALTHASAR, H. U., Ensayos Teológicos, p. 40-41.

${ }^{69}$ Para obter uma visão panorâmica deste assunto, ver: SATTLER, D.; SCHNEIDER, T., Doutrina sobre Deus, p. 80-97.
} 
por Balthasar com a argumentação mais conhecida sobre este tema na tradição cristã. Trata-se do diálogo com as cinco vias de Santo Tomás de Aquino, citadas por Balthasar na obra aqui estudada. ${ }^{70}$ Estas vias também respondem de modo positivo à pergunta pela existência de Deus, utilizando a teologia natural como recurso, isto é, fundamentando o seu discurso na experiência empírica. Vale a pena confrontar estes dois autores de épocas distintas a fim de perceber melhor como Balthasar interage com a tradição cristã.

As cinco vias de Santo Tomás são apresentadas na Suma Teológica ${ }^{71}$ e respondem à questão utrum Deus sit - Deus existe? -, desdobrando o argumento cosmológico da Antiguidade clássica.

É interessante observar a influência cultural da cristandade sobre a argumentação do doutor Angélico. Ele evidencia que todos (fiéis da cristandade) aceitam a ideia de Deus ao concluir as cinco vias com "[...] o que todos chamam Deus". Diante de uma população identificada com o cristianismo, estas vias não tiveram o objetivo principal de converter "infiéis", mas de oferecer aos crentes um ponto de referência da fé ancorado na realidade empírica, dando solidez ao sentimento religioso.

De outra parte, a fundamentação por meio de provas da existência de Deus foi feita de modo inovador no que diz respeito ao método. Ao retomar a tradição aristotélica, Santo Tomás reintroduziu na teologia o método positivo, confrontando-o com o modo negativo de discorrer sobre Deus vigente na época, de matiz platônico. ${ }^{72}$ Não obstante esta mudança, deve-se observar que a teologia negativa continuou sendo essencial para o autor medieval: "Mas como de Deus só podemos saber o que Ele não é, e não o que é, não se trata tanto de considerar como Ele é quanto como não é". ${ }^{73}$ Logo, o método positivo que perpassa as cinco vias foi realizado somente em nível dos efeitos de Deus visíveis na criação, não em sua essência divina. ${ }^{74}$

As três primeiras vias levam em conta a experiência de ordem encontrada na natureza e realizam a pergunta metafísica pela causa eficiente (originante) do universo. Tal demonstração foi tida por séculos como a prova metafísica por antonomásia. ${ }^{75}$ A primeira via parte do movimento dos seres atestado

\footnotetext{
${ }^{70}$ BALTHASAR, H. U., Ensayos Teológicos, p. 30-32.

${ }^{71}$ ST I, q. 2, a. 3.

${ }^{72}$ SATLER, D.; SCHNEIDER, T., Doutrina sobre Deus, p. 86.

${ }^{73}$ ST I, q. 3.

${ }^{74}$ ST I, q. 2, a. 1.

${ }^{75}$ CAFFARENA, J. G., Pruebas de la existencia de Dios, col. 334.
} 
pelos sentidos humanos. Ora, dos seres que se movem, nenhum é movido por si; todos dependem de outro. Da relação estabelecida entre ato (movimento) e potência (movimento futuro), Santo Tomás infere por indução a existência de um primeiro motor do universo não movido por nenhum outro e que é puro ato, chamado com o nome de Deus. A segunda via é muito semelhante e diz respeito à ideia de causa eficiente. Utilizando a lógica de causa e efeito, o doutor angélico infere a impossibilidade de algo ser a causa eficiente de si próprio; as coisas do mundo são produtos de causas eficientes. Descartando a possibilidade de continuar até o infinito na série das causas, ele apontou para a necessidade de uma causa eficiente primeira, chamada Deus.

A terceira via é considerada o centro do arrazoado e consiste na explanação da relação entre o ser possível e o ser necessário. Santo Tomás, observando a experiência fundamental dos seres vivos de nascer e de perecer, chegou à conclusão da contingência da natureza. Tudo o que existe não é necessário e poderia não existir. E, se em algum momento nada houvesse, seria impossível que algo começasse a existir por si. Ora, como o mundo de fato existe e é contingente, Santo Tomás deduziu a existência de um ente que seja pura necessidade e que possa tornar realidade tudo o que é meramente possível, chamado aqui de Deus. Em suma, nestes três primeiros caminhos, chega-se à conclusão da necessidade de um ser infinito e único como fundamento do universo.

Na quarta via, de maior repercussão para o argumento de Balthasar, Santo Tomás parte das gradações de bondade, de verdade e de nobreza verificáveis nos entes. Ele intui que entre os entes exista um que encerre no máximo grau estas propriedades essenciais do ser.

[...] [O] que se encontra no mais alto grau em determinado gênero é causa de tudo que é desse gênero: assim, o fogo, que é quente no mais alto grau, é causa do calor de todo e qualquer corpo aquecido [...]. Existe então algo que é, para todos os outros entes, causa de ser, de bondade e de toda a perfeição: nós o chamamos Deus". ${ }^{76}$

Mesmo que o exemplo do fogo não seja algo plausível para os interlocutores de hoje, acostumados com as explicações da física moderna, a quarta via não perde o seu valor enquanto discurso metafísico. Nesta

\footnotetext{
${ }^{76}[\ldots][M]$ axime tale in aliquo genere, est causa omnium quae sunt illius generis: sicut ignis, qui est maxime calidus, est causa omnium calidorum [...]. Ergo est aliquid quod omnium entibus est causa esse, et bonitatis, et cuiuslibet perfectionis: et hoc dicimus Deum (ST I, q. 2, a. 3).
} 
demonstração está implícito o tema platônico da participação, segundo o qual todos os entes participam de modo limitado daquele que é o puro ser, isto é, a verdade, a bondade e a beleza infinitas. ${ }^{77} \mathrm{O}$ modo de participação dos entes nas propriedades deste ser absoluto ocorre, segundo o medieval, por derivação, por causalidade, em uma clara releitura deste tema à luz da filosofia de Aristóteles.

Em relação às três vias anteriores, centradas na causa eficiente, este caminho teve o mérito de desenvolver a pergunta pelo fim último. Aqui está o questionamento metafísico mais profundo, na medida em que parte da tendência do ser humano de abrir-se para o infinito como último foco de atração, algo que Santo Agostinho chamou de "inquietude". A abertura para o bem maior, o fascínio pela beleza da natureza, a busca constante da verdade em meio às várias propostas de felicidade perpassam a existência humana e apontam para algo que a sobrepassa infinitamente. Não pode ser irreal aquilo para o qual o ser humano anseia. ${ }^{78}$ Balthasar intuiu e desenvolveu com profundidade este pensamento metafísico, quando ele entreviu em seu caminho de acesso a Deus o amor da mãe como um fragmento de bondade, de beleza e de verdade deste Ser Absoluto.

Enfim, a quinta via é de ordem cosmológica e está baseada na ordem do mundo. A percepção da organização das coisas, especialmente das realidades viventes, inferiu a necessidade de um ser inteligente ordenador do universo e que se identifica com Deus. Tal prova já era afirmada pelos padres apologistas e refuta a teoria segundo a qual a vida na terra seria o resultado de mera combinação casual de elementos físicos e químicos.

Em uma visão de conjunto, afirma-se que as vias de Santo Tomás constituíram uma renovada síntese das respostas da tradição teológica cristã para a pergunta da existência de Deus a partir do método positivo aristotélico.

Vale a pena mencionar que a crítica moderna tendeu a rechaçar as tentativas de provar a existência de um ser transcendente. A consciência humana está limitada à realidade empírica categorial o que impossibilitaria a demonstração de Deus. José Gómez Caffarena discorre sobre o questionamento de Kant, crítico severo da metafísica, sobre a argumentação destas provas por tratarem de possibilidades meramente lógicas, sem comprovação com a experiência e por fazerem da existência um conceito que implica perfeição. ${ }^{79}$

\footnotetext{
${ }^{77}$ ST I, q. 2, a. 3.

${ }^{78}$ CAFFARENA, J. G., Pruebas de la existencia de Dios, col. 333.

${ }^{79}$ CAFFARENA, J. G., Pruebas de la existencia de Dios, col. 335-356.
} 
Diante de tais críticas, é importante explicitar que as exposições de vias de acesso ao transcendente nunca tiveram o intuito de serem provas cabais, mas apenas quiseram aproximar a razão humana da fé no mistério do Deus revelado como o criador do universo. É certo que tanto Tomás de Aquino quanto Balthasar tinham consciência destas limitações, dificuldades que não inibiram a proposição de um caminho metafísico. ${ }^{80}$

\section{Conclusão}

Balthasar não desacredita no método metafísico de Tomás de Aquino, usado pela tradição, para mostrar a possibilidade da pessoa chegar a Deus, mas dá razão a ele, pois entende que o Aquinate mostra a preferência à ética geral ao bem próprio por parte do ser humano. ${ }^{81}$ Todavia, ao pressupor o amor maternal como o ponto de partida para o acesso a Deus, mesmo considerando a analogia entis, ele acrescenta algo novo ao caminho tradicional, ou seja, ele dá uma roupagem existencial ao caminho até então metafísico, tendo a inteligência humana como o substrato possibilitador deste processo, pois considera a existência humana como parte imprescindível deste processo e, assim, acrescenta um dado novo ao arcabouço metafísico do caminho pessoal de descoberta de Deus, classificando este processo de meta-antropológico. ${ }^{82}$

Ao retomar a sua proposta de caminho para a descoberta de Deus, Balthasar entende que todo ser humano, ilimitado em seu ser espiritual, se abre para Deus, ser infinito, a partir de quatro afirmações: o filho é um apaixonado pela mãe, mesmo sendo um ser diferente de sua mãe, e, assim, todo ser é um; que esse amor é bom, portanto, todo Ser é bom; que esse amor é verdadeiro, portanto, todo o Ser é verdadeiro; e que esse amor evoca a alegria, portanto, todo Ser é lindo. ${ }^{83}$

\footnotetext{
${ }^{80}$ A este propósito, pode servir a advertência de Bernard Sesboüe sobre o caráter racional e ao mesmo tempo misterioso das provas sobre a veracidade de uma religião: "Une religion qui expliquerait tout ne serait plus qu'une philosophie. Une religion qui exclurait la raison ne serait qu'une superstition aveugle. Une religion qui ne montre pas la vraie nature de l'homme, qui n'apprend pas à aimer et n'adorer que Dieu, qui ne fournit pas des preuves historiques de sa véracité, est une religion fausse. Le véritable esprit religieux consiste dans la recherche sincère du vrai Dieu et de la vérité. Les preuves de la religion ne peuvent qu'être à la fois claires et obscures" (SESBOË, B., Introduction à la theologie, p. 42).

${ }^{81}$ BALTHASAR, H. U., Ensayos Teológicos, p. 31.

${ }^{82}$ BALTHASAR, H. U., My work, p. 114.

${ }^{83}$ BALTHASAR, H. U., My work, p. 114.
} 
Este processo é coerente com a forma específica de Balthasar refletir a teologia, porquanto ele considera ser necessário chegar a uma integração de todos os elementos básicos da condição humana para pensar a Deus, a fé, a Igreja, Nossa Senhora e a espiritualidade cristã, tendo como ponto de apoio a assertiva de que a razão humana deve estar aberta ao infinito, além de se apoiar em numerosas traduções dos Santos Padres, nos teólogos da Idade Média e dos tempos modernos. ${ }^{84}$

Em relação às cinco vias, Balthasar consegue intuir o fundamento meta-antropológico subjacente na argumentação da quarta via: o olhar humano que capta, como que em um lampejo, o Ser infinito no fragmento do amor humano da mãe. Nesse sentido, ele utilizou uma visão antropológica mais ampla que o autor medieval na elaboração do seu caminho para acessar a Deus: um caminho em que se sobressai não apenas a razão, mas o amor humano.

Enfim, todo o caminho para a busca de Deus supõe a reconquista da "simplicidade de coração" (Mt 6,22), superando a autossuficiência característica dos tempos de hoje, e, com humildade, descobrir ser possível ver além do mundo factível e, desse modo, abrir o coração para Deus, que é amor (1Jo 4,8), superando a crescente falta de Deus no mundo de hoje. Só o amor é capaz de "salvar" a humanidade. Por isso, é preciso despertar a "mística do amor", reconstruindo o anthropos pelo amor.

\section{Referências bibliográficas}

BALTHASAR, H. U. Ensayos Teológicos. Spiritus Creator. Madrid: Encuentro e Cristandad, 2004. v.III.

BALTHASAR, H. U. Erich Przywara. In: VANZAN, P.; SCHULTZ, H. J. Lessico dei teologici del secolo XX. Mysterium Salutis / Supllemento. Brescia: Queriniana, 1978. p. 347-354.

BALTHASAR, H. U. My work: in retrospect. San Francisco: Ignatius Press, 1993.

CAFFARENA, J. G. Pruebas de la existencia de Dios. In: RAHNER, K. (Org.). Sacramentum mundi. Barcelona: Herder, 1976. col. 327-338. (Enciclopedia Teológica, II).

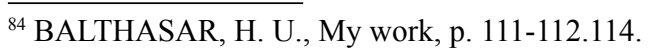


DALFERTH, I. U. Trascendenza e mondo secolare. Orientamento della vita alla Prezenza ultima. Brescia: Queriniana, 2016.

DENZINGER, H.; HÜNERMANN, P. Compêndio dos símbolos, definições e declarações de fé e moral. São Paulo: Paulinas / Loyola, 2007.

DOTOLO, C. Teologia e postcristianesimo. Um percorso interdisciplinare. Brescia: Queriniana, 2017.

FRANSCISCO, PP. Carta Encíclica Laudato Si' sobre o cuidado da casa comum (24 de maio de 2015). Disponível em: <http://www.vatican.va/ content/francesco/pt/encyclicals/documents/papa-francesco_20150524_ enciclica-laudato-si.html>. Acesso em: 16 mai. 2019.

GAUTIER, B. Balthasar em Dialogue avec Barth. Paris: Désclée de Brouwer, 2014.

JOÃO PAULO II, PP. Carta Encíclica Evangelium Vitae sobre o valor e a inviolabilidade da vida humana (25 de março de 1995). Disponível em: $<$ http://www.vatican.va/content/john-paul-ii/pt/encyclicals/documents/hf_jpii_enc_25031995_evangelium-vitae.html >. Acesso em: 20 mai. 2019.

PRZYWARA, E. Analogia entis. In: HÖFER, J; RAHNER, K. Lexikon für Teheologie und Kirche. Freiburg: Herder, 1986. col. 469-473.

SATTLER, D.; SCHNEIDER, T. Doutrina sobre Deus. In: SCHNEIDER, T. (Org.). Manual de dogmática. Petrópolis: vozes, 2018. p. 80-97. v.I.

SESBOË, B. Introduction à la theologie. Histoire et intelligence du dogme. Paris: Salvator, 2017.

TOMÁS DE AQUINO. Suma teológica: teologia, Deus, Trindade: I Parte, questões 1-43. São Paulo: Loyola, 2016. v.1.

TOMÁS DE AQUINO. De veritate. Hamburg: Meiner, 1986.

Geraldo Luiz Borges Hackmann

Doutor em Teologia pela Pontificia Università Gregoriana Docente do Curso de Teologia e do Programa de Pós-Graduação em Teologia da Pontifícia Universidade Católica do Rio Grande do Sul

Porto Alegre / RS - Brasil

E-mail: gborgesh@pucrs.br 


\section{Rafael Martins Fernandes}

Doutor em Teologia pela Pontificia Università Lateranense Bolsista do PNPD-CAPES pelo Programa de Pós-Graduação em Teologia da Pontifícia Universidade Católica do Rio Grande do Sul Porto Alegre / RS - Brasil E-mail: padrerafaelfernandes@gmail.com

Recebido em: 30/01/2019 Aprovado em: 11/03/2020 